Introduction to the Theory of Equations

By Assoc. Prof. Lois Wilfred Griffiths.

Second edition. Pp. ix +278. (New York: John Wiley and Sons, Inc.; London: Chapman and Hall, Ltd., 1947.) 18s. net.

$\mathrm{T}$ HE contents of this volume fall into three clearly marked sections. Chapters 1-4 (pp. 1-105) lead up to the location and calculation of the real roots of a real algebraic equation; the cubic and quartic equations are studied in Chapter 2, as a preliminary to theorems on the general equation. Sturm's theorem provides for locating the roots of the general equation, but the only method of calculation expounded is that of Horner, explained very lucidly with attention to the justification of contracted processes. Chapters 5-7 (pp. 106-235) deal with determinants, introduced for orders 2 and 3 and extended to order $n$, and with systems of linear equations. The connexion between a set of solutions of such a system and the rank of the augmented matrix of the system is set out carefully; but some hints on what can be done to alleviate the tedious process of solving a numerical set of linear equations would have been welcome. Chapter 8 sets out the axiomatic theory of the complex number, familiarity with the technique having been assumed in the early chapters. Chapter 9 deals with symmetric functions of the roots of an algebraic equation, a topic the academic elegance of which has caused it to be over-elaborated in some text-books ; Prof. Griffiths rightly relegates it to the subordinate position it should occupy in an introductory account.

\section{Chemical and Physical Investigations on Dairy} Products

By H. Eilers, R. N. J. Saal and M. van der Waarden. (Monographs on the Progress of Research in Holland.) Pp. xv+215. (New York and Amsterdam : Elsevier Publishing Co.; London: Cleaver-Hume Press, Ltd., 1947.) 21s, net.

THE series of publications, of which this book on dairy research is one, deals with the investigations carried on by Dutch scientific workers during the German occupation of the Netherlands. The Dutch are a pertinacious people, and the 'mere trifles' of enemy occupation, oppression and near-starvation do not seem very seriously to have depressed the high quality, although they may have somewhat diminished the quantity, of their research in dairy chemistry and physies.

This volume contains, in effect, three communications. The first, by Eilers, deals with the colloid chemistry of skim milk, and includes studies of the calcium-casein-phosphate complex, the proteins in milk denaturable by heat, and the physical and physico-chemical changes occurring in skim milk on concentration. The second, by Saal and Heukelom, is concerned with the oxidation-reduction potential of the complicated biological system of milk and the only slightly less difficult system of butter-plasma. The third, by van der Waarden, approaches the com. mercially important, as well as academically interesting, group of problems associated with the chemical processes underlying the deterioration of butter.

Each article provides a short but well-documented survey of the field (though for obvious reasons there are few references after 1939) and each presents a considerable body of original research. This wellwritten and eminently readable volume is commended to every chemist or physical chemist interested in dairy research or dairy technology. H. D. K.
The Skyscraper Hive

By Father M. Dugat. Authorized translation of "La Ruche Gratteciel à Plusiers Reines" by Norman C. Reeves. Pp. xvi $+78+4$ plates. (London : Faber and Faber, Ltd., 1948.) 8s. 6d. net.

LTHOUGH no competent beekeeper is likely $A$ to disagree with the general statement that "The secret of large surpluses (of honey) is large colonies", a good many beekeepers will heartily disagree with M. Dugat's system of colony management. His system is indeed little more than an extension of the two-queen system of management which has been tried out very thoroughly in the United States and other countries since at least the beginning of this century, and has not been found to yield any notable increase in honey crop per queen over various singlequeen systems.

All the data at present available as a result of much experimentation lead one to suggest that the success which M. Dugat has achieved is not so much due to his multi-queen system as to those other methods of management which he employed with his 'skyscraper' hives, and which are equally applicable to single-queen colonies. Such methods, which involve the partial separation of young bees from the older field bees and, by giving the queen every encouragement to lay to her full capacity, lead to the development of very powerful colonies, and at the same time help to control swarming, have long been known to give good results.

One cannot help but feel that M. Dugat might have obtained even larger crops of honey if he had avoided the once popular but now largely discredited practice of completely de-queening his colonies just before the honey-flow, a practice which frequently results in a loss of what may perhaps be termed "colony morale'.

Colin G. ButLer

\section{Principles and Practice of the Rorschach Personality Test}

By W. Mons. Pp. 164. (London: Faber and Faber, Ltd., 1947.) 12s. $6 d$. net.

CINCE the Swiss psychiatrist, H. Rorschach, $\checkmark$ published his fascinating "Psychodiagnostik" in 1932, considerable effort has been devoted in several countries to elaborating the methods of scoring and interpreting the test responses. Nevertheless, the somewhat forbidding notation in current use has given the accumulated mass of data the semblance of esoteric lore and the test itself has acquired what the late William Stern called a "monosymptomatic despotism". It is refreshing, therefore, to read Dr. Mons' clear and restrained account of the techniques and interpretation of the Rorschach 'ink-blot' test, an account based on extensive experience with Service and civilian patients and on the examination of a thousand clerical records.

With the difficulties of the novice in mind, Dr. Mons painstakingly explains how to administer the test, how to classify the responses according to a widely used, though somewhat pretentious, notation, and how to evaluate the significance of the responses so as to yield an assessment of the personality, particularly its 'structural' features. Several new formulæ useful for diagnostic purposes are suggested.

It is to be hoped that this useful manual will stimulate workers to pursue much more rigorously than hitherto methods of validating the test which could greatly improve its potential value as a diagnostic tool. JOHN COHEN 